Original article

Perinatology Vol. 30, No. 1, March, 2019

https://doi.org/10.14734/PN.2019.30.1.8
Kyungju Kim, MD', Ji Won Jang, MD', Ji Hyeon Moon, MD', Jeonghee Shin, $\mathrm{MD}^{\prime}$, Eun Hee Lee, MD', Byung Min Choi, MD, PhD', Young Sook Hong, MD, PhD', Min Jeong $\mathrm{Oh}, \mathrm{MD}, \mathrm{PhD}^{2}$

Departments of ${ }^{1}$ Pediatrics, 2Obstetrics and Gynecology, Korea University College of Medicine, Seoul, Korea

Received: 3 August 2018 Revised: 16 September 2018 Accepted: 13 October 2018

Correspondence to Young Sook Hong, MD, PhD Department of Pediatrics, Korea University College of Medicine, 148 Gurodong-gil, Guro-gu, Seoul 08308, Korea

Tel: +82-2-2626-1229

Fax: +82-2-2626-1249

E-mail: hongys@korea.ac.kr

Copyright@ 2019 by The Korean Society of Perinatology

This is an Open Access article distributed under the terms of the Creative Commons Attribution Non-Commercial License (http://creativecommons.org/ license/by-nc/4.0/), which permits unrestricted non-commercial use, distribution, and reproduction in any medium, provided that the original work is properly cited.

\section{The Relationship between Histological Cho- rioamnionitis and Bronchopulmonary Dys- plasia in Low-Birth Weight Infants: Changes of C-Reactive Protein in Bronchopulmonary Dysplasia}

Objective: Intrauterine inflammation caused by chorioamnionitis has been related with various perinatal morbidities which increase the risk of bronchopulmonary dysplasia (BPD). C-reactive protein (CRP) is a well known biomarker of inflammation. We aimed to investigate the relationship between histological chorioamnionitis (HCA) and BPD, and also to observe the changes of CRP in BPD.

Methods: Low-birth-weight infants (LBWIs) admitted to the neonatal intensive care unit between January 2011 and October 2017 were reviewed. Perinatal morbidities associated with BPD including maternal HCA were observed. Also, changes of CRP were analyzed.

Results: A total of 584 LBWIs were analyzed and 168 (28.8\%) had HCA and 46 (7.9\%) had BPD. The development of BPD was associated with gestational age, birth weight, 1 and 5 minutes Apgar scores, the presence of preterm premature rupture of membrane, prenatal antibiotics, respiratory distress syndrome (RDS), ventilator application, early onset sepsis, necrotizing enterocolitis, intraventricular hemorrhage, retinopathy of prematurity, patent ductus arteriosus and HCA. The multiple logistic regression model for BPD showed that the risk factors of BPD were lower gestational age, lower birth weight, patent ductus arteriosus (PDA). Chorioamnionitis was not a significant risk factor for BPD (aOR, 1.477; 95\% Cl, 0.376-5.806). Infants with BPD were likely to have higher CRP on day 0 and day 7 . Conclusion: Our study suggests that the primary risk factors of BPD in LBWIs are lower gestational age, lower birth weight, RDS, ventilator application and PDA rather than HCA. In infants with BPD, CRP was significantly higher on day 0 and day 7 .

Key Words: Chorioamnionitis, Bronchopulmonary dysplasia, C-reactive protein, Inflammation

서론

기관지폐 형성이상(bronchopulmonary dysplasia, BPD)은 미숙아 및 저체중아에서 많이 발생하는 만성 폐질환으로서, 미숙아의 생존율이 증가함에 따라 그 발생률도 증가하고 있다. 이는 폐에서 폐포와 혈관의 발달이 억제되어 발생하며 출생 전후기의 염증과 관련된다고 알 려져 있다. ${ }^{1,2}$ 퇴원 후에도 지속적인 산소흡입, 반복적인 호흡기 감염이나 그로 인한 재입원 을 필요로 할 뿐 아니라, 신경발달에도 영향을 미친다는 보고가 있으므로 ${ }^{3,4}$ 위험인자의 예측 을 통한 예방이 중요하다. ${ }^{5}$

조직학적 융모양막염은 산모의 염증 반응으로서 양막, 융모막, 융모막판에 호중구가 침윤 된 경우이며 제대혈관의 염증(funisitis) 등 태아의 염증이 동반되기도 한다.,6 미숙아의 25$40 \%$ 가 자궁내 염증과 관련이 있다.

최근 태반의 조직검사 시행이 증가함에 따라 병리학적으로 증명된 융모양막염과 신생아 의 여러 질환과의 관계에 대한 연구가 늘어나면서 태아기의 자궁내 염증이 신생아의 예후에 
큰 영향을 준다고 알려져 있다. ${ }^{8-10}$ 하지만 조직학적 융모양막염 단일질환과 $\mathrm{BPD}$ 와의 관계에 대한 연구에서는 상반된 결과들이 보고되고 있어 여전히 논란이 되고 있다. ${ }^{11-13}$

$\mathrm{C}$-반응단백(C-reactive protein, $\mathrm{CRP})$ 은 염증의 중요한 생 물학적 지표로서 임상에서 널리 사용되고 있다. 이 지표들이 융 모양막염 등 자궁내 염증이 있을 때 증가한다는 보고들이 있으 나 ${ }^{14} \mathrm{BPD}$ 발생과의 관련 여부 특히 출생 후 $\mathrm{CRP}$ 치의 변화에 대 한 연구는 많지 않다.

본 연구에서는 조직학적 융모양막염과 $\mathrm{BPD}$ 발생과의 관련성 에 대하여 알아보고 위험인자 및 $\mathrm{CRP}$ 변화를 관찰하였다.

\section{대상 및 방법}

\section{1. 대상}

2013년 1월부터 2017년 10월까지 고려대학교 의료원에서 태 반 조직검사를 시행한 출생 체중 $2,500 \mathrm{~g}$ 미만의 신생아 599명 중 월경 후 나이 36 주 이전에 사망한 신생아 및 선천 기형 15 명 을 제외한 584명을 대상으로 하였다.

\section{2. 정의}

$\mathrm{BPD}$ 는 산소 분압 $21 \%$ 를 초과한 산소요법을 28 일 이상 시행 하고, 재태 기간 32 주 미만인 경우 월경 후 연령 36주와 퇴원시 점, 재태 기간 32 주 이상인 경우 생후 8주와 퇴원시점 중 빠른 시기에 공기(room air)로 유지되는 경우를 경증, 산소 분압 $30 \%$ 미만의 산소요법이 필요한 경우를 중등도, 산소 분압 $30 \%$ 이상 의 산소 혹은 기계환기나 양압환기와 같은 호흡보조가 필요한 경우를 중증으로 정의하였다. ${ }^{15}$

조직학적 융모양막염의 진단은 고려대학교 의료원 병리과에 서 병리학적 소견에 따라 이루어졌으며 Benirschke 법 ${ }^{16}$ 에 의거 하여 양막과 융모탈락막, 제대, 융모막판의 다형핵 백혈구 침윤 정도에 따라 분류하였다.

조기 양막 파수는 18 시간 이상인 경우, 조기 신생아 패혈증은 출생 48시간 이내에 임상적 증상이 있으면서 혈액 배양검사상 양성인 경우로 정의하였다.

\section{3. 자료수집방법}

연구 대상자들과 산모의 의무기록을 검토하여 임상 양상, 주 산기 합병증 여부를 후향적으로 조사하였다. 조사된 변수는 재 태 기간, 출생 체중, 성별, 1 분 및 5 분 아프가 점수, 분만방식, 조 기 양막 파수 유무, 신생아 호흡곤란 증후군(respiratory distress syndrome, RDS), 동맥관 개존증의 동반 유무, 인공호흡기 사용
유무, 1-4등급 뇌실내 출혈, 1-4기 미숙아 망막증 발생 여부이 며, 출생 0, 3, 7일째 환아의 혈 액내 CRP 검사소견(TBA-2000FR; Toshiba Medical System Co., Tochigi, Japan) 등이다.

\section{4. 통계분석}

조직학적 융모양막염 두 군 간의 비교에서 연속변수는 Student's t-test 또는 Mann Whitney Utest를, 범주형 변수는 Chisquare test 또는 Fisher's exact test를 사용하였다. BPD가 발 생할 위험인자를 찾기 위하여 단순 로지스틱을 시행하였고 그 중 의미 있는 변수에 대하여 다중 로지스틱 회귀분석을 사용하 였다. Adjusted odds ratio (aOR)와 95\% 신뢰구간(95\% confidence interval [CI])을 구하였으며 $P$ 값이 0.05 미만인 경우 통 계적 유의성이 있다고 판단하였다. 수집된 자료는 IBM SPSS Statistics version 20 (IBM Co., Armonk, NY, USA)을 사용하 여 통계분석을 시행하였다.

\section{결과}

총 599명의 저체중출생아 중 36 주 이전 사망아 및 선천 기형 15 명을 제외한 584 명의 산모 및 신생아를 대상으로 의무기록을 분석하였다.

\section{1. 조직학적 융모양막염 유무에 따른 두 군 간 특성의 비교}

총 584명 중 조직학적 융모양막염이 있는 군을 group 1 , 없는 군을 group 2로 하였으며, 각각 168명(28.8\%), 416명(71.2\%) 이었다. 평균 재태 기간은 group 1이 $32.7 \pm 3.7$ 주, group 2가 $34.4 \pm 2.94$ 주로 group 1에서 더 짧은 재태 기간을 보였으며, 각 그룹을 재태 기간에 따라 세분하였을 때 group 1에서 재태 기간 32 주 미만의 비율이 더 높았다. 출생 체중은 각각 $1,767 \pm 499 \mathrm{~g}$, $1,953 \pm 464 \mathrm{~g}$ 으로 group 1에서 더 작은 출생 체중을 보였다. $\mathrm{BPD}$ 는 총 46명이었으며 group 1에서 25명(14.9\%), group 2에 서 21명(5.0\%)으로 group 1에서 BPD의 발생률이 더 높았다. 특 히 경증의 $\mathrm{BPD}$ 가 중등도 및 중증에 비하여 유의하게 많이 발생 하였다. 또한 재태 기간별로 $\mathrm{BPD}$ 의 발생을 세분하였을 때 두 그 룹 모두에서 28 주 미만이 대부분을 차지하였으나 두 그룹 간 유 의한 차이는 없었다. 이밖에 조기 양막 파수, RDS, 기계적 환기, 뇌실내 출혈, 동맥관 개존증 또한 통계적으로 유의하게 group 1 에서 더 높은 비율을 나타내었다(Table 1).

\section{BPD 발생 위험인자}

총 584명에 대해 단순 로지스틱 회귀분석 시행시 RDS, 기계 
적 환기는 $\mathrm{BPD}$ 군 46 명 모두에게 있어 분석에서 제외하였다. 그 외 인자들의 분석 결과 재태 기간, 출생 체중, 1 분 및 5 분 아프가 점수, 조기 양막 파수, 출산 전 항생제 사용, 조기 패혈증, 괴사 장염, 뇌실내 출혈, 미숙아 망막병증, 동맥관 개존증 및 조직학 적 융모양막염이 통계적으로 유의한 위험인자임을 알 수 있었 다. 이후 다중 로지스틱 회귀분석으로 각 위험인자를 보정하여 위험도를 예측하였다. 그 결과 재태 기간이 짧을수록, 출생 체중 이 작을수록, 동맥관 개존증 존재시 $\mathrm{BPD}$ 의 위험성이 증가하였 다. aOR은 각각 0.659 (95\% CI, 0.439-0.989), 0.996 (95\% CI, 0.993-0.999), 4.259 (95\% CI, 1.082-16.767)였다. 괴사 장염 시 BPD 위험성은 aOR 0.133 (95\% CI, 0.025-0.889)으로 낮은 것으로 보였다. 조직학적 융모양막염은 다른 위험인자를 보정

Table 1. Demographic and Clinical Findings in Low-birth-weight Infants with and without Histological Chorioamnionitis

\begin{tabular}{lccr}
\hline & HCA & No HCA & $P$-value \\
\hline N & $168(28.8)$ & $416(71.2)$ & \\
\hline Gestational age (weeks) & $32.7 \pm 3.7$ & $34.4 \pm 2.94$ & $<0.001$ \\
\hline$<28$ & $21(12.5)$ & $13(3.1)$ & $<0.001$ \\
\hline $28-31$ & $33(19.6)$ & $52(12.5)$ & 0.027 \\
$\geq 32$ & $114(67.9)$ & $351(84.4)$ & 0.016 \\
\hline Birth weight (g) & $1,767 \pm 499$ & $1,953 \pm 464$ & $<0.001$ \\
Male sex & $81(48.2)$ & $199(47.8)$ & 0.934 \\
Cesarean section & $94(56.0)$ & $303(72.8)$ & $<0.001$ \\
Apgar, 1 minute & $6.3 \pm 2.47$ & $6.7 \pm 2.01$ & 0.059 \\
Apgar, 5 minutes & $8.3 \pm 1.71$ & $8.6 \pm 1.45$ & 0.069 \\
PROM (>18 hours) & $56(33.3)$ & $72(17.3)$ & $<0.001$ \\
GDM & $26(15.7)$ & $75(18.0)$ & 0.460 \\
Early onset sepsis & $3(1.8)$ & $4(1.0)$ & 0.415 \\
Ventilator application & $67(39.9)$ & $106(25.5)$ & 0.001 \\
RDS & $50(29.8)$ & $54(13.0)$ & $<0.001$ \\
IVH & $36(21.4)$ & $51(12.3)$ & 0.005 \\
\hline BPD & $25(14.9)$ & $21(5.0)$ & $<0.001$ \\
Mild & $11(6.5)$ & $3(0.7)$ & $<0.001$ \\
\hline Moderate to severe & $14(8.3)$ & $18(4.3)$ & 0.054 \\
\hline Gestational age (weeks) & & & \\
\hline$<28$ & $19(76.0)$ & $12(57.2)$ & 0.174 \\
\hline 28-31 & $6(24.0)$ & $7(33.3)$ & 0.484 \\
\hline PDA & $0(0.0)$ & $2(9.5)$ & 0.203 \\
\hline Val & $51(30.4)$ & $93(22.4)$ & 0.042 \\
\hline
\end{tabular}

Values are presented as mean \pm standard deviation or number (\%). Abbreviations: HCA, histological chorioamnionitis; PROM, premature rupture of membrane; GDM, gestational diabetes mellitus; RDS, respiratory distress syndrome; IVH, intraventricular hemorrhage; BPD, bronchopulmonary dysplasia; PDA, patent ductus arteriosus.
하였을 때 $\mathrm{aOR} 1.477$ (95\% CI, 0.376-5.806)로 통계학적으로 유의한 차이는 없으나 $(P=0.419)$ 좀 더 많은 대상자에서 연구가 필요할 것으로 보인다. 출생 7일째 $\mathrm{CRP}$ 는 $\mathrm{BPD}$ 군에서 $\mathrm{aOR} 1.081$ (95\% CI, 1.020-1.145)로 유의하게 높게 나타났다(Table 2). 대 부분의 BPD 발생이 32 주 미만에서 발생한 것을 바탕으로(Table 1) 재태 기간 32 주 미만의 그룹만을 대상으로 통계분석을 시행 하였다(데이터는 나타내지 않음). 그 결과 유의한 위험인자는 재태 기간과 뇌실내 출혈이었으며 각각 aOR은 $0.465(95 \% \mathrm{CI}$, 0.265-0.816)와 4.429 (95\% CI, 1.530-12.822), P-value는 0.008 과 0.006 였다. $\mathrm{HCA}$ 의 aOR은 1.863 (95\% CI, 0.6515.327), $P$-value 0.246 로서 재태 기간 32 주 미만의 그룹에서도 유의한 위험인자가 될 수 없었다.

\section{3. $\mathrm{BPD}$ 유무에 따른 CRP치의 변화}

$\mathrm{BPD}$ 유무에 따라 출생 0 일째, 3 일째, 7 일째 $\mathrm{CRP}$ 중앙치를 통 계분석한 결과 출생 0 일째 $\mathrm{CRP}$ 가 $\mathrm{BPD}$ 가 있는 군과 없는 군에 서 각각 $0.15 \mathrm{mg} / \mathrm{dL}$ (0.10-0.32), $0.13 \mathrm{mg} / \mathrm{dL}$ (0.10-0.20)로서 $\mathrm{BPD}$ 군에서 유의하게 높게 나타났다 $(P=0.027)$. 또한 출생 7 일 째 $\mathrm{CRP}$ 도 각각 $0.57 \mathrm{mg} / \mathrm{dL}(0.34-1.79), 0.30 \mathrm{mg} / \mathrm{dL}(0.18-$ $0.62)$ 로서 $\mathrm{BPD}$ 군에서 의미 있게 높게 나타났다 $(P<0.001)$. 출 생 7일째 $\mathrm{CRP}$ 최고치는 각각 $64.58 \mathrm{mg} / \mathrm{dL}, 87.38 \mathrm{mg} / \mathrm{dL}$ 였다 (Table 3).

\section{고찰}

본 연구는 조직학적 융모양막염이 $\mathrm{BPD}$ 발생 위험을 증가시 키는지 알아보고 특히 이에 관여하는 위험인자를 파악하고자 하였다. 또한 $\mathrm{BPD}$ 발생군에서 출생 후 시간에 따른 $\mathrm{CRP}$ 치 변화 를 관찰하였다. 지금까지 알려진 $\mathrm{BPD}$ 발생의 위험인자 중 출생 전 인자로는 짧은 재태 기간, ${ }^{17}$ 태아 자궁내 성장 부전이나 임신 나이에 비하여 작은 체중, ${ }^{18}$ 유전학적 감수성 19 등이 있고 출생 후 인자로는 기계환기, 감염, 동맥관 개존 등 20 이 있다. 이외에도 최근 여러 연구에서 $\mathrm{BPD}$ 가 출생 전후기의 자궁내 염증과 관련 이 있다고 보고되고 있다. ${ }^{21-23}$ 즉, 양막내 감염과 염증이 내독소 를 매개로 태아 및 신생아에 전신 염증 반응을 일으키고, 이어서 기계적 환기, 산소 독성, 신생아 감염 등의 출생 후 인자들이 기 도와 간질의 손상된 염증 반응을 더욱 증폭시킨다. 이러한 증폭 된 염증 반응에는 싸이토카인, 케모카인, 성장인자 등이 관련되 어 있어 폐포화와 폐혈관 발달에 영향을 미친다고 알려져 있다. 양수와 태아 제 대혈의 전염증성 싸이토카인(proinflammatory cytokine) 증가는 $\mathrm{BPD}$ 의 독립적 위험인자로 여러 연구에서 보 
Table 2. Multiple Logistic Regression for Bronchopulmonary Dysplasia

\begin{tabular}{lcccc}
\hline Variable & OR $(95 \% \mathrm{Cl})$ & $P$-value & Adjusted OR $(95 \% \mathrm{Cl})$ & $P$-value \\
\hline Gestational age (weeks) & $0.376(0.291-0.487)$ & $<0.001$ & $0.659(0.439-0.989)$ & 0.044 \\
Birth weight (g) & $0.995(0.993-0.996)$ & $<0.001$ & $0.996(0.993-0.999)$ & 0.004 \\
Apgar, 1 minute & $0.507(0.429-0.599)$ & $<0.001$ & $0.666(0.430-1.031)$ & 0.069 \\
Apgar, 5 minutes & $0.410(0.327-0.514)$ & $<0.001$ & $1.239(0.730-2.102)$ & 0.428 \\
PROM & $3.105(1.637-5.889)$ & 0.001 & $2.334(0.469-11.614)$ & 0.300 \\
\hline Prenatal antibiotics & $4.110(2.016-8.379)$ & $<0.001$ & $1.915(0.400-9.175)$ & 0.416 \\
Early onset sepsis & $17.398(3.766-80.370)$ & $<0.001$ & $0.142(0.012-1.629)$ & 0.117 \\
NEC & $4.800(1.985-11.606)$ & $<0.001$ & $0.133(0.020-0.889)$ & 0.037 \\
IVH & $3.919(2.048-7.502)$ & $<0.001$ & $2.475(0.550-11.136)$ & 0.238 \\
ROP & $74.525(32.144-172.784)$ & $<0.001$ & $1.133(0.230-5.577)$ & 0.878 \\
PDA & $19.358(8.773-42.717)$ & $<0.001$ & $4.259(1.082-16.767)$ & 0.038 \\
HCA & $3.288(1.785-6.057)$ & $<0.001$ & $1.477(0.376-5.806)$ & 0.419 \\
Day 7 CRP (mg/dL) & $1.057(1.011-1.105)$ & 0.014 & $1.081(1.020-1.145)$ & 0.009 \\
\hline
\end{tabular}

Abbreviations: OR, odds ratio; $\mathrm{Cl}$, confidence interval; $\mathrm{PROM}$, premature rupture of membrane; NEC, necrotizing enterocolitis; IVH, intraventricular hemorrhage; ROP, retinopathy of prematurity; PDA, patent ductus arteriosus, HCA, histological chorioamnionitis.

Table 3. Comparison of C-reactive Protein Levels according to the Presence of Bronchopulmonary Dysplasia

\begin{tabular}{lccr}
\hline & \multicolumn{1}{c}{ BPD } & No BPD & $P$-value \\
\hline CRP $(\mathrm{mg} / \mathrm{dL})$ & & & \\
Day 0 & $0.15(0.10-0.32)(n=46)$ & $0.13(0.10-0.20)(n=522)$ & 0.027 \\
Day 3 & $1.59(0.68-4.78)(n=45)$ & $1.12(0.55-2.75)(n=498)$ & 0.072 \\
Day 7 & $0.57(0.34-1.79)(n=39)$ & $0.30(0.18-0.62)(n=455)$ & $<0.001$ \\
\hline
\end{tabular}

Values are presented as median (25-75th interquartile).

Abbreviations: BPD, bronchopulmonary dysplasia; CRP, C-reactive protein

고된 바 있다. ${ }^{21}$ 조직학적 융모양막염은 ureaplasma와 같은 감 염 또는 그외 pathological process에 의하여 발생하게 된다. 임 상적 융모양막염 없이도 발생하는 무증상 융모양막염은 조직학 적 융모양막염의 40-90\%에 달한다. ${ }^{24}$ 융모양막염이 $\mathrm{BPD}$ 의 위 험을 높인다는 결과를 보여주는 연구로는 Watterberg 등25이 출 생 24시간 내에 측정한 기관지 폐포 세척액의 interleukin (IL)1 의 수치를 기반으로 하여 처음으로 융모양막염과 $\mathrm{BPD}$ 발생의 연관성에 대해 기술한 바 있으며 이후 Yoon 등 26 은 BPD가 있는 신생아에서 전염증성 싸이토카인인 IL-6, tumor necrosis factor alpha, $\mathbb{L}-1 \mathrm{~b}, \mathbb{I L}-8$ 이 더 높다는 것을 발견하였고 이는 태아의 폐 염증이 출생 전부터 이미 발생하였다는 것을 의미한다고 하였 다. 또한 15,000 예의 메타분석에서는 27 재태 기간과 출생 체중 을 보정한 후에도 조직학적 융모양막염과 $\mathrm{BPD}$ 사이에 유의한 양의 상관관계를 보여주었다. 융모양막염은 $\mathrm{BPD}$ 발생의 위험 요인인 미숙아 출생 가능성을 증가시키고 만성 염증과정을 유 도함으로써 미성숙한 폐가 출생 후 손상에 더욱 취약하도록 한
다. 동물실험에서도 융모양막염으로 출생전 염증에 노출된 경 우 폐 발달에 있어서 성숙효과를 일으키는 28 반면 구조적으로 변형되어 나타남으로써29 출생 후 손상에 대하여 더욱 취약해지 는 것으로 보았다. ${ }^{30}$ 기계 환기요법, 과산소 및 저산소증 등이 이 런 손상을 일으키는 요인으로 알려져 있으며 조기 패혈증 및 후 기 패혈증 모두 $\mathrm{BPD}$ 발생의 독립적 위험인자 ${ }^{1,23}$ 로 보고되고 있 다. Choi 등 ${ }^{31}$ 도 출생 후 염증이 $\mathrm{BPD}$ 를 유발하였으며 또한, 지질 다당류로 출산 전 염증을 유발시켰던 동물에서는 출생 후 전신 염증에 의한 $\mathrm{BPD}$ 발생을 방지하는 효과가 있다고 보고하였다.

본 연구 결과에서는 $\mathrm{BPD}$ 의 발생에 조직학적 융모양막염은 위험요소가 되지 못하였다. 조직학적 융모양막염이 있는 군에 서 없는 군보다 $\mathrm{BPD}$ 가 더 많이 발생하고 그중에서도 경증 $\mathrm{BPD}$ 가 중증도 또는 중증 $\mathrm{BPD}$ 보다 많이 발생하였으나 여러 변수를 고려 하여 $\mathrm{BPD}$ 에 미치는 영향을 분석한 결과 위험요소가 되지는 않았 다. 이는 다른 연구에서와 비슷한 결과를 보이는데 Torchin 등 11 은 조산아를 대상으로 한 코호트 연구에서 조산이나 조기 양막 파수 그룹에서 $\mathrm{BPD}$ 와 조직학적 융모양막염은 상관관계가 보이 지 않았다고 보고하였다. 이외에도 몇몇의 연구에서는 융모양 막염과 $\mathrm{BPD}$ 간 상관관계가 없거나 오히려 폐 성숙을 촉진시켜 $\mathrm{BPD}$ 의 발생을 감소시킨다는 결과를 보여주었다. ${ }^{13,32-35}$

이처럼 이전 연구들의 상반된 결과의 원인으로는 통일되지 못 한 융모양막염과 $\mathrm{BPD}$ 정의, 서로 다른 연구집단, 염증과 Ureaplasma와 같은 감염균 사이 기여도의 정도, 출판 편향 등에 기 인한다고 보고되기도 하였다. ${ }^{36}$

$\mathrm{BPD}$ 발생을 막기 위해서는 자궁내 혹은 출생 후 감염, 출생 후 
손상 등을 방지할 필요가 있으며 이러한 위험군을 인지하기 위 하여 염증 반응에 관여하는 생물표지자(biomarker)에 대한 연 구가 이루어지고 있다. ${ }^{37,38} \mathrm{CRP}$ 는 염증의 지표로 임상에서 널리 사용되고 있는 급성기 반응물질로서 감염이나 조직 손상에 반 응하여 간에서 생성되어 혈액으로 분비된다. ${ }^{37}$ Samejima 등 ${ }^{14}$ 은 조직학적 융모양막염, 특이 funisitis가 산모뿐 아니라 신생아의 $\mathrm{CRP}$ 를 높인다고 보고한 바 있다. 건강한 신생아에서 $\mathrm{CRP}$ 는 생 리적으로 생후 24-48시간에 최고치를 나타낸다. ${ }^{39}$ 그러나Chiesa 등 40 이 건강한 미숙아를 대상으로 출생 후 $\mathrm{CRP}$ 변화를 연구한 결과 출생시 $0.1 \mathrm{mg} / \mathrm{L}$ (0.01-0.64), 생후 36시간에 최고치 1.7 $\mathrm{mg} / \mathrm{L}$ (0.1-4.7), 생후 90시간 경에 $0.7 \mathrm{mg} / \mathrm{L}(0.1-4.7)$ 로 감소 하여 건강한 만삭아에 비하여 더 낮은 값과 더 짧은 $\mathrm{CRP}$ 반응을 나타낸다고 보고하였다. 또한 재태 기간이 양성 효과를 가지고 있으며 염증 전 위험인자에 의해서도 영향을 받는다고 하였다.

본 연구에서는 대상아 중 일부(출생 $0,3,7$ 일별 $\mathrm{N}$ 수: $\mathrm{BPD}, 46$, 45, 39명; no BPD, 522, 498, 455명)에서 출생 0일, 3일, 7일째 $\mathrm{CRP}$ 를 측정하여 $\mathrm{BPD}$ 유무에 따라 $\mathrm{CRP}$ 치의 변화를 알아보았 다. 연구 결과 모든 대상에서 이전 연구와 같이 ${ }^{40}$ 생후 3 일째 최 고치를 나타내었다. BPD군에서는 출생 0 일째 $0.15 \mathrm{mg} / \mathrm{dL}$ (0100.32), 3일째 $1.59 \mathrm{mg} / \mathrm{dL}$ (0.68-4.78), 7일째 $0.57 \mathrm{mg} / \mathrm{dL}$ (0.341.79 )로 출생 0 일 및 7일째 $\mathrm{CRP}$ 가 $\mathrm{BPD}$ 없는 군에 비하여 통계 적으로 유의하게 높은 수치를 보였다. 이는 패혈증을 제외한 경 우에도 같은 결과를 나타내었다. 앞서 언급한 바와 같이 $\mathrm{BPD}$ 발 생은 출생 전 인자 및 출생 후 인자가 복합적으로 작용한다는 점 을 고려하여 볼 때 이러한 결과는 출생 당일 신생아의 CRP가 출 생 전 자궁내 염증 상태를 반영하며 이후의 $\mathrm{CRP}$ 가 출생 후 감염 혹은 비감염적 원인의 출생 후 염증 상태를 반영하여 추후 $\mathrm{BPD}$ 예측의 생물표지자로 사용될 수 있는 가능성에 대하여 고려해 볼 수 있다. 그러나 결과가 생물학적으로 큰 차이가 없고 $\mathrm{CRP}$ 측정이 이루어진 신생아만을 대상으로 후향적인 연구를 시행하 였으므로 추후 더 많은 신생아를 대상으로 전향적 연구가 필요 할 것으로 보인다.

본 연구는 $2,500 \mathrm{~g}$ 미만의 저체중출생아를 대상으로 하였고 경증의 $\mathrm{BPD}$ 를 포함하는 등 범위를 넓게 하여 연구를 시행하였 다. 그 결과 $\mathrm{BPD}$ 의 주요 위험인자는 짧은 재태 기간, 작은 출생 체중, 괴사 장염, 동맥관 개존증이었으며 산모의 조직학적 융모 양막염은 유의한 상관성을 찾을 수 없었다. 이는 재태 기간 32 주 미만의 그룹으로 그 대상을 축소하여도 동일한 결과를 나타내 었다.

현재까지 산모의 염증 상태를 다룬 연구는 많으나 본 연구와 같이 출생 후 신생아에서 염증지표의 변화를 1 주간 시간별로 관 찰한 경우는 드물다. 본 연구의 제한점은 연구 대상자에 $\mathrm{BPD}$ 에
이환된 신생아의 수가 적어 신뢰도가 떨어질 수 있다는 점이며 태반 조직검사 결과의 자세한 기술이 부족하다는 것이다. 또한 후향적 연구로서 모든 신생아를 대상으로 $\mathrm{CRP}$ 측정이 이루어 지지 않았으며 $\mathrm{CRP}$ 를 측정한 환아들만을 대상으로 통계분석을 시행하여 선택편향이 작용할 수 있다는 점이다. 조직학적 융모 양막염과 $\mathrm{BPD}$ 의 관계에 대한 연구는 앞으로 통일된 조직학적 융모양막염의 진단기준으로 더 많은 대상자에서 연구가 행해져 야 할 것으로 보인다.

\section{References}

1) Speer CP. Inflammation and bronchopulmonary dysplasia: a continuing story. Semin Fetal Neonatal Med 2006;11:354-62.

2) Kim CJ, Romero R, Chaemsaithong P, Chaiyasit N, Yoon BH, Kim YM. Acute chorioamnionitis and funisitis: definition, pathologic features, and clinical significance. Am J Obstet Gynecol 2015;213(4 Suppl):S29-52.

3) Malavolti AM, Bassler D, Arlettaz-Mieth R, Faldella G, Latal B, Natalucci G. Bronchopulmonary dysplasia-impact of severity and timing of diagnosis on neurodevelopment of preterm infants: a retrospective cohort study. BMJ Paediatr Open 2018;2:e000165.

4) You JY, Shu C, Gong CH, Liu S, Fu Z. Readmission of children with bronchopulmonary dysplasia in the first 2 years of life: a clinical analysis of 121 cases. Zhongguo Dang Dai Er Ke Za Zhi 2017;19:1056-60.

5) Bozzetto S, Carraro S, Tomasi L, Berardi M, Zanconato S, Baraldi E. Healthrelated quality of life in adolescent survivors of bronchopulmonary dysplasia. Respirology 2016;21:1113-7.

6) Redline RW. Classification of placental lesions. Am J Obstet Gynecol 2015;213(4 Suppl):S21-8.

7) Gravett MG, Hitti J, Hess DL, Eschenbach DA. Intrauterine infection and preterm delivery: evidence for activation of the fetal hypothalamicpituitary-adrenal axis. Am J Obstet Gynecol 2000;182:1404-13.

8) Balany J, Bhandari V. Understanding the impact of infection, inflammation, and their persistence in the pathogenesis of bronchopulmonary dysplasia. Front Med (Lausanne) 2015;2:90.

9) Eriksson L, Haglund B, Odlind V, Altman M, Ewald U, Kieler H. Perinatal conditions related to growth restriction and inflammation are associated with an increased risk of bronchopulmonary dysplasia. Acta Paediatr 2015;104:259-63.

10) Stranak Z, Feyereisl J, Korcek P, Feyereislova S, Krofta L. Procalcitonin is more likely to be released by the fetus rather than placental tissue during chorioamnionitis. Biomed Pap Med Fac Univ Palacky Olomouc Czech Repub 2016;160:499-502.

11) Torchin H, Lorthe E, Goffinet F, Kayem G, Subtil D, Truffert $P$, et al. Histologic chorioamnionitis and bronchopulmonary dysplasia in preterm infants: the epidemiologic study on low gestational ages 2 cohort. J Pediatr 2017;187:98-104.e3.

12) Matsumura $H$, Ichiba $H$, Ohnishi S, Saito M, Shintaku H. Histologic chorioamnionitis, amniotic fluid interleukin 6 , krebs von den lungen 6 , and 
transforming growth factor $\beta 1$ for the development of neonatal bronchopulmonary dysplasia. Jpn Clin Med 2017;8:1179066017696076.

13) Kaneko M, Sato M, Ogasawara K, Imamura T, Hashimoto K, Momoi N, et al. Serum cytokine concentrations, chorioamnionitis and the onset of bronchopulmonary dysplasia in premature infants. J Neonatal Perinatal Med 2017;10:147-55.

14) Samejima T, Takechi K. Elevated C-reactive protein levels in histological chorioamnionitis at term: impact of funisitis on term neonates. J Matern Fetal Neonatal Med 2017;30:1428-33.

15) Jobe AH, Bancalari E. Bronchopulmonary dysplasia. Am J Respir Crit Care Med 2001;163:1723-9.

16) Salafia $C M$, Weigl $C$, Silberman $L$. The prevalence and distribution of acute placental inflammation in uncomplicated term pregnancies. Obstet Gynecol 1989;73:383-9.

17) Stoll BJ, Hansen NI, Bell EF, Shankaran S, Laptook AR, Walsh MC, et al. Neonatal outcomes of extremely preterm infants from the NICHD Neonatal Research Network. Pediatrics 2010;126:443-56.

18) Palta M, Gabbert D, Weinstein MR, Peters ME. Multivariate assessment of traditional risk factors for chronic lung disease in very low birth weight neonates. The Newborn Lung Project. J Pediatr 1991;119:285-92.

19) Yu KH, Li J, Snyder M, Shaw GM, O'Brodovich HM. The genetic predisposition to bronchopulmonary dysplasia. Curr Opin Pediatr 2016;28:31823.

20) Ali Z, Schmidt P, Dodd J, Jeppesen DL. Bronchopulmonary dysplasia: a review. Arch Gynecol Obstet 2013;288:325-33.

21) Glaser K, Speer CP. Pre and Postnatal inflammation in the pathogenesis of bronchopulmonary dysplasia, in Bronchopulmonary Dysplasia, edited by Bhandari V, Cham, Springer International Publishing, 2016, p55-77.

22) Viscardi RM. Perinatal inflammation and lung injury. Semin Fetal Neonatal Med 2012;17:30-5.

23) Speer CP. Chorioamnionitis, postnatal factors and proinflammatory response in the pathogenetic sequence of bronchopulmonary dysplasia. Neonatology 2009;95:353-61.

24) Palmsten K, Nelson KK, Laurent LC, Park S, Chambers CD, Parast MM. Subclinical and clinical chorioamnionitis, fetal vasculitis, and risk for preterm birth: a cohort study. Placenta 2018;67:54-60.

25) Watterberg KL, Demers LM, Scott SM, Murphy S. Chorioamnionitis and early lung inflammation in infants in whom bronchopulmonary dys plasia develops. Pediatrics 1996;97:210-5.

26) Yoon BH, Romero R, Jun JK, Park KH, Park JD, Ghezzi F, et al. Amniotic fluid cytokines (interleukin-6, tumor necrosis factor-alpha, interleukin-1 beta, and interleukin-8) and the risk for the development of bronchopulmonary dysplasia. Am J Obstet Gynecol 1997;177:825-30.
27) Hartling L, Liang Y, Lacaze-Masmonteil T. Chorioamnionitis as a risk factor for bronchopulmonary dysplasia: a systematic review and meta-analysis. Arch Dis Child Fetal Neonatal Ed 2012;97:F8-17.

28) Kramer BW, Kallapur S, Newnham J, Jobe AH. Prenatal inflammation and lung development. Semin Fetal Neonatal Med 2009;14:2-7.

29) Kramer BW, Ladenburger A, Kunzmann S, Speer CP, Been JV, van Iwaarden JF, et al. Intravenous lipopolysaccharide-induced pulmonary maturation and structural changes in fetal sheep. Am J Obstet Gyneco 2009;200:195 e1-10.

30) Thomas W, Speer CP. Chorioamnionitis: important risk factor or innocent bystander for neonatal outcome? Neonatology 2011;99:177-87.

31) Choi CW, Lee J, Oh JY, Lee SH, Lee HJ, Kim BI. Protective effect of chorioamnionitis on the development of bronchopulmonary dysplasia triggered by postnatal systemic inflammation in neonatal rats. Pediatr Res 2016 79:287-94

32) Paananen $R$, Husa AK, Vuolteenaho R, Herva R, Kaukola T, Hallman M. Blood cytokines during the perinatal period in very preterm infants: relationship of inflammatory response and bronchopulmonary dysplasia. J Pediatr 2009;154:39-43.e3.

33) Plakkal N, Soraisham AS, Trevenen C, Freiheit EA, Sauve R. Histologica chorioamnionitis and bronchopulmonary dysplasia: a retrospective cohort study. J Perinatol 2013;33:441-5.

34) Ballard AR, Mallett LH, Pruszynski JE, Cantey JB. Chorioamnionitis and subsequent bronchopulmonary dysplasia in very-low-birth weight infants: a 25-year cohort. J Perinatol 2016;36:1045-8.

35) Stimac M, Juretić E, Vukelić V, Matasić NP, Kos M, Babić D. Effect of chorioamnionitis on mortality, early onset neonatal sepsis and bronchopulmonary dysplasia in preterm neonates with birth weight of $<1,500$ grams. Coll Antropol 2014;38:167-71.

36) Choi CW. Chorioamnionitis: is a major player in the development of bronchopulmonary dysplasia? Korean J Pediatr 2017;60:203-7.

37) Ansar W, Ghosh S. C-reactive protein and the biology of disease. Immunol Res 2013;56:131-42.

38) Lee J, Bang YH, Lee EH, Choi BM, Hong YS. The influencing factors on procalcitonin values in newborns with noninfectious conditions during the first week of life. Korean J Pediatr 2017;60:10-6.

39) Chiesa C, Signore F, Assumma M, Buffone E, Tramontozzi P, Osborn JF, et al. Serial measurements of $C$-reactive protein and interleukin- 6 in the immediate postnatal period: reference intervals and analysis of ma ternal and perinatal confounders. Clin Chem 2001;47:1016-22.

40) Chiesa C, Natale F, Pascone R, Osborn JF, Pacifico L, Bonci E, et al. C reac tive protein and procalcitonin: reference intervals for preterm and term newborns during the early neonatal period. Clin Chim Acta 2011;412: 1053-9. 